\title{
The Light and Twilight of Zera Yaekob's Philosophy for the Eminence of European Enlightenment
}

\author{
Kahsu Abrha Belew \\ Department of Civics and Ethical Studies, College of Social Sciences and Humanities, Raya University, Maichew, Ethiopia \\ Email: \\ kahsuabrha16@gmail.com \\ To cite this article: \\ Kahsu Abrha Belew. The Light and Twilight of Zera Yaekob's Philosophy for the Eminence of European Enlightenment. Advances in \\ Sciences and Humanities. Vol. 6, No. 1, 2019, pp. 1-8. doi: 10.11648/j.ash.20200601.11
}

Received: Otober 9, 2019; Accepted: November 4, 2019; Published: January 6, 2020

\begin{abstract}
The objective of this paper is to scrutinize the role of Zera Yaekob's philosophy of the current existing European enlightenment period/age of reason which was claimed to be the philosophy of Immanuel Kant. Zera Yaekob's philosophy is systematically ignored and neglected by Euro-philosophers because of various reasons. Underscoring the following research questions is pertinent to resolve such neglecting: Is Zera Yaekob's philosophy really hollow of the European enlightenment? Why Euro-philosophers systematically ignored his philosophy, nevertheless, his philosophical outlook still working there? To harangue these questions, therefore, the researcher employed philosophical methods of qualitative/analysis and phenomenology. Zera Yaekob's rationalistic philosophy seems to, like the ocean, have diverse echelons. The usual daily activities have been documented by philosophical philosophers, starting from his mouthpiece Welde Hewot till now according to a Canadian philosopher Claude Sumner. Now a day, several Neo-Zera Yaekobian's are emerging on the philosophical scene of metaphysics, epistemology, ethics, gender and the like. The streams - the sincere pillar of the ocean that mixes water across the world and it embodies the most philosophical echelons of enlightenment. This is why Zera Yaekob's philosophy is considered as a premium spring/notebook of western enlightenment philosophy. The researcher argues that the Enlightenment culminated their climax with Zera Yacob of Abyssinia in Africa than Immanuel Kant in Europe. Moreover, the paper also takes into account how his philosophical scene governs contemporary African philosophy. Above all, surprisingly but terribly also, they (European) are there with the light of enlightenment because we (Africans) are here with the twilight of counterenlightenment.
\end{abstract}

Keywords: Philosophy, Ethiopia, Zera Yaekob’s Philosophy, European Enlightenment

\section{Introduction}

Zera Yaekob of Axum was the main principal Ethiopian philosopher and he has contributed to the existing European enlightenment. Besides, he was a sound branded philosopher and theologian. Hence, the arguer believes that the world has understood wrongly about Ethiopian philosophy in general and Zera Yaekob's profound philosophical work in particular Accordingly, there are questions that getting in doubt here and there on the actual and authorship of Ethiopian philosophy and European enlightenment. For instance, is an Ethiopian philosophy, in fact, philosophized by Zera Yaekob? And is Zera Yaekob really an Ethiopian [1].

As a result, two arguments flourished: (I) some arguers argued that his philosophy was not aroused by himself and it was not an actual philosophy, (II) in contrast some others denied this. The paper tries to scrutinize and show Zera Yaekob is a native Ethiopian philosopher and his philosophy is a key figure for today's European enlightenment tradition (he is considered as a stepping stone for European enlightenment). The paper defends that Zera Yaekob used strong ethnocentric form and structure of his usage of language, religion, and culture. Hence, his philosophy was not drawn from a euro-centric approach when examined in terms of his philosophy's structure and context [2].

\section{An Ethiopian Philosopher: A Brief About Zera Yaekob}

This magnificent philosopher and theologian was born in Axum; obviously Axum is a birthplace of Ethiopian and 
African Christianity and civilization. However, he philosophically doubts on all religions and admits that he himself stands for a pure "deism". In Ethiopia's history, the autobiography of a learned man is already in great frequency. At all, we know Philosophy may be considered as the parent science, in that it has given birth to other sciences like natural, physical and social sciences. As various philosophers claimed defining philosophy is not simple and visible like Mathematics, Physics, Psychology, Geography and the like. One of the reasons that make defining philosophy is difficult is that it lacks a distinct subject matter [3].

As mentioned above disciplines like biology, psychology, history, physics - all deal with a specific body of subjects. If you asked biologist or psychologist what their studies deal with, they could probably answer without too much disagreement, however, not so with philosophy. Philosophers often disagree on their subject matter. One of the reasons is that philosophy deals more/general with issues than with specific subjects. Issues make up the content of philosophy.

While some issues have remained throughout the development of philosophical thought many have not. Some have faded with the passage of time or have become part of the subject matter of other disciplines, such as physics or psychology. Even those issues that have remained in the province of philosophy have changed as various thinkers and ages have considered them.

Despite, as Miller wrote in his book Questions That Matter: An Invitation to Philosophy, philosophy can be defined based on its etymology or original word. The word philosophy is derived from the two Greek words Philo, meaning love and Sophia, which means wisdom. Thus, philosophy literally means "love of wisdom" [4] (Miller, 1984: 3). Philosophers were not satisfied with etymological meanings of philosophy and they disagreed upon it rather they have connoted the term philosophy in terms of working and finally they agreed on it. Accordingly, the working definition of philosophy is as follows: "is the attempt to think rationally and critically about the most important questions. It is the study of the most fundamental and general concepts and principles involved in thought, action and reality" [Quoted in 4].

Now lets' proceed to Zera Yaekob's autobiography. In this context, as Sumner noted in his tremendous book entitled Ethiopian Philosophy:

He was born in the land of the priests of Aksum. But ' $I$ ' am the son of a poor farmer in the district of Aksum; the day of my birth is 25th of August 1592 A. D., the third year of the reign of [King] Ya'aqob. By Christian baptism 1 was named Zär' a Ya'aqob, but people called me WärqYe [5].

Therefore, Zera Yaekob was born in Axum - Abyssinia (contemporary Ethiopia) in 1592. And during his lifetime, he studied normative religion at Axum by a priest, but he had nothing to do with modern academics and knowledge. He came to believe that religion can free ordinary people from ignorance and allow them to be more productive and comfortable lives. He believes that the mind of human beings first has to be free from uncritical ways of thinking and that was why Zera Yaekob promoted a rationalist approach to religion, metaphysics, epistemology, and gender. For instance, Zera Yaekob portrayed religion in the metaphysical scene as follows:

I remained ten years in this type of study; I learned the interpretations, both of the Frang ${ }^{1}$ and of our own scholars. Often times their interpretation did not agree with my reason, but I withheld my opinion and hid in my heart all the thoughts of my mind. Having returned to my native Aksum, 'I taught for four years. But this period was not peaceful: for in the XIX year of King Susanyos, while 'a Jwons, a Frang, was 'abunä, two years [after his arrival] great persecution spread over all Ethiopia. The king accepted the faith of the Frang, and from that time on persecuted all those who did not accept it. The Frang say this and this" or the Copts say that and that, and 1 did not say: "This is good, that is bad," but 1 said: "All these things are good if we ourselves are good." Hence 1 was disliked by all: the Copts took me for a Frang, the Frang for a Copt... [6].

In 1667, his student Welde Hewet has encouraged him so as to collect and wrote his fragmented philosophies (roughly twenty-page) treatises, which were concurrently the first autobiography and the first philosophical work in Ethiopian history. He died in 1692, but Welde Hewet later put down his own thoughts as well, very much in the same vein as those of his master, though marked by a less personal style and at just slightly greater length. The two treatises (their common title, hatata, means something like 'investigation' 'or inquiry') are primarily concerned with showing the errors of various religions, and they correspondingly treat of various moral topics; they are also concerned to put confidence in God on a rational footing, and so to defend the goodness of God in the face of evil and injustice [7].

In fact, his commentary was given the title of the book called "Hatata Ze Zera Yaekob" and it was published by his mouthpiece known as Welde Hewet. He abdicated, and died not much later; Susanyos son Fasiladas (1632-1667) lost no time affirming his commitment to the Orthodox faith, drawing the sectarian conflict to a close. ZeraYaecob came out of hiding, finally making his way to the town of Enfraz, not far from Gondar and Lake Tana. Here, he found employment doing philosophical writing and teaching children of the king.

\section{The Untold Philosophy}

In a strict sense, an Ethiopian philosophy was originated in the sixteenth century at Axum by a theologian and philosopher, Zera Yaekob. This seeming contradiction can be understood if we realize that philosophy itself is ambiguous. His philosophy was designated through reason alone, which rigorously and critically illuminates metaphysical, epistemological, gender, and ethical questions. Therefore, there was a paradigm shift from faith-based human life to reason based human life. This movement or tradition is imagined as "enlightenment" by European language and connotation.

1 Non Ethiopians regard as Frang (white people). 
But this trend systematically and intentionally ignored by euro-philosophers. Zera Yaekob's philosophy is so much an area or topic within philosophy as it is a set of religious original questions about the full range of philosophical issues. His philosophy deals with metaphysics, epistemology, ethics, and methodology, as well as with the problems and opportunities of religious philosophizing, and does so in ways that cover the range of the "Natural Theology"rational/non rational approach to God divide in modern philosophy, especially Descartes and Kant's philosophical methodology. The best we can hope to do here will be hitting some high points, and direct the reader to more complete introductions for further philosophizing [8].

The central concern of Zera Yaekob's philosophy in the sixteenth century, often to the triumph of its practitioners, is over the existence and nature of Ethiopian philosophy. Historically, it is clear that the academic study of Zera Yaekob's philosophy has its roots in various religious interpretations of the Bible and Quran, and yet many Ethiopian and African philosophers argue that Ethiopian philosophy is limited or reducible to that history. Questions about Zera Yaekob philosophy's existence by Ethiopians, Africans and non-Africans have often amounted to an implicit dismissal of Ethiopia, Africa and world, as those questions come with the presumption that there is no philosophy in Ethiopia, philosophy by Zera Yaekob, even though if philosophy practiced and existed in Ethiopia then it should be taken into account it was conducted by Western missionaries and the onus is on those who claim there is to prove it.

The problem is not as easily dealt with as in 'Greek philosophy', where there is a history of textuality that allows the philosopher to refer to a historically specific set of ideas and issues that have been part of a conversation over time. Ethiopian philosophy, even Zera Yaekob's philosophy except for Hateta of Zera Yaekob ${ }^{2}$ has comparatively few texts, and very fewer sustained conversations among those texts.

Accordingly, this insufficiency has governed some of the important questions; for instance, is there something both uniquely Zera Yaekob's and fundamentally philosophical within Ethiopian structure and content? If there is, what is it? If there is really a doubt here, can it (or should it) be resolved? Is it by finally privileging one or the other side of the doubt, for example, by arguing that Zera Yaekob's philosophy fundamentally resides in some universal feature such as reason, or conversely, that reason itself always fundamentally particularly and located, related to race, culture, history or politics?

Accordingly, as Sumner quoted from d'Abdadie's catalog (1859):

This professor born in Aksum, here expounds his doubts on all religions and admits that he himself stands for pure deism. In Ethiopian, the autobiography of a learned man is already a great rarity: this one is more remarkable still on account of its great naiveté, by the details it contains on the

2 A book written by inciation of his editor named Welde Hewet and it signifying as "inquiry" or "investigation". When Zera Yaekob wrote his book, he has used reason alone. customs and notions of contemporary history one could vainly seek for elsewhere. The authors speak the expulsion of the Portuguese and the stigmatic's. Fasillades, victims of this king. This work, written in an attractive style, is in an attractive style, is in Geez, and finds in it the $m, \rho$ : instead of $\boldsymbol{\omega}$ F,..: Amharic, a kind of pea, which, according to tradition, would have become a usual cereal only since the beginning of the $6^{\text {th }}$ century [9].

He has shown the pros and cons of philosophizing and does so in ways that cover the scope of the analytic/continental divide in Western philosophy. Ethiopian philosophy is a species of Ethiopian thought, which involves metaphysical, epistemological, ethical, religious questions, raised by critical engagements with ideas in Ethiopian thinking, structure, tradition, culture, religion and their hybrid, or mixed, forms of worldwide.

For many, his philosophy is necessarily rooted in the traditional belief systems of European ethnic and linguistic groups. Hence his philosophy is the only philosophy if it is modeled closely on European forms of disciplinary methodology. However, locating Ethiopian philosophy in the disciplinary and interdisciplinary matrix can be difficult. While for some Zera Yaekob's philosophy has Ethiopian spirituality, reasoning, religion, cultural tradition, and activism, it has nothing to do with the euro-philosophies.

\section{Zera Yaekob and Kant on Enlightenment}

According to Barnett, In historical studies and indeed most fields of the humanities, the term modernity and Enlightenment are so frequently linked that either term almost automatically evokes the other. It has become an accepted commonplace, part of the historical canon that modernity began in the Enlightenment [10].

However, this quotation begs a simple but vicious question: "what was the general character of the intellectual phenomenon we term the Enlightenment" [11]? And who is the author of this philosophical school of thought? As mentioned in the introduction the aim of the paper is to scrutinize the 16th-century Ethiopian philosopher so-called Zera Yaekob whose philosophy was remarkable for his time and place. He studied the interpretation of the Holy Scriptures. He says that the interpretation based on fearing theologian's interpretation and Ethiopian theologians is quite varied. Zera Yaekob would have inclusive knowledge of early Christian and Islamic contemplation and commentary on the Bible and Quran.

Moreover, Zera Yaekob's philosophy/enlightenment has been studied for a very long time in Axum for many decades in North Ethiopia. The first scholar who translated Zera Yaekob's work of philosophy (since it was written in Geez version) to English and published in 1976 was the Canadian scholar Claude Sumner. Sumner believes that now is a time to think about the factual claims of Zera Yaekob around and general stance in order to welcome the philosophical vista on his 
scripts. In this regard, Ntep argued in his article as follows:

The arch philosopher of the Enlightenment Immanuel wrote after the 17 th century a text titled, "Religion within the confines of bare reason"; but Zera Yacob and his student Walda Heywat had already philosophized long before Kant in East Africa on religion and faith within the framework and confines of reason. We can read the outcome, fruit, and the result of their philosophical pursuits in chapter $\mathrm{V}$ of the "Treatise" of Walda Heywat (and Zera Yacob): "That I may not be misled in my faith; I believe nothing except what God demonstrated to me by the light of my reason" [12].

Zera Yaekob principally comprehends God and nature, and he severely inclined by their references and application of God's word. Even though he made a logical Christian and Quran teaching, but because of misinterpretation of the two hollies books Zera Yaekob was explicitly rejected some of them doctrines like Mosses and Mohammed's view. He is still possible to become aware of the Christian foundation in his tradition and interpretation.

In addition to his philosophy, we must take into account his socio-cultural context. As the $16^{\text {th }}$ century Ethiopian, his attitude towards ethnic groups and nations would have been shaped by that. The language he used demonstrates a strong ethnocentric feeling, emotion and the logic of linguistics. Therefore, philosophical about Zera Yaekob who came up with a lot of philosophical panoramas; this also attributed to the European enlightenment before anybody else.

Now let's portray how Zera Yaekob's philosophy exclusively taken as a departure/stepping stone for the existence of European enlightenment/ age of reason, particularly for the giant German philosopher Immanuel Kant In this context, various scholars plainly agreed that the enlightenment or sometimes so-called age of reason is an endowment of Western's, Western civilization, and the period of Renaissance. Among the main prominent figures of enlightenment the following are some of them: René Descartes (1596-1650), Voltaire (1694-1778), Thomas Hobbes (1580-1679), John Locke (1632-1704), Jean-Jacques Rousseau (1712-1778), Montesquieu (1689-1755), Immanuel Kant (1724-1804) and the like [13]. But in this paper, only the two euro-philosophers: Descartes and Kant are my concern since they have assumed to be an icon of the European enlightenment (modernity), philosophy, science, and civilization.

Before comparing Zera Yaekob and Kant's philosophy of enlightenment let's start with the definition of enlightenment, what refers enlightenment to? As Kant connoted in his tremendous book entitled Answer the Question: What is Enlightenment? It can be defined as:

Enlightenment is man's emergence from himself-imposed immaturity. Immaturity is the inability to use one understanding without guidance from another. Self-incurred is the tutelage when its cause lies not in lack of understanding, but rather of resolve and courage to use it without direction from another: Sapere Aude! (Latin translated: Dare to know, from, Horance). Have the courage to use your own mind: this is the motto of enlightenment [14].
Furthermore, "'reason' becomes the unifying and central point of the century, expressing all that it longs and strives for, and all that it achieves" [15]. Kant is the well-known German philosopher of enlightenment. Besides, Kant also entirely figures of modern social and political philosophy. He wants to know what enlightenment is. And he wrote this in a very tricky political situation. The enlightenment is the social and intellectual movement that expresses extremely critical. According to Kant, enlightenment is "the human beings emergence from his self-incurred minority" [16].

"Minority": inability to make use of one's own understanding without direction from another". Meaning that Kant believes that the overall majority of people are not able to make use of understanding in any few ways without someone's direction from the aristocracy or monarchy. Few people who are, officially, formally are allowed to make their understanding in this way and there were social institutions that prohibited for doing so. Kant sees enlightenment like a movement, social-cultural arrangement. We have a selfincurred minority. We have to look inward than outlook.

Moreover, Lavine stated in "the power of reason" that to know the truths of nature and the capacity of the human spirit to determine, express, and achieve what is good for human beings" [17]. He also stated that "Renaissance art reaffirmed the dignity and capacity for the goodness of man as a rational and sentient being". Here is the point that has a vertical relevance to the Zera Yakob philosophy, Louden suggested that "pure reason does not undermine religion" [Quoted in 17]. In this context, Zera Yaekob was right in rationalizing God; eventually, he has accomplished his argument when he lived in the cave.

Therefore, the argument is addressed to the question of who's who of enlightenment? Accordingly, twofold arguments emerged: (I) Europeans in general and Immanuel Kant, in particular, was the pioneer of enlightenment, so it has nothing to do with Africans-Ethiopians. (II) Paradoxically, Ethiopian philosopher Zera Yaekob was philosophically ignored by euro-philosophers; as a result, the world has very little information about his philosophy. However, this enlightenment was originated by the Ethiopian philosopher (ever will exist again like him) in AxumEthiopia. As a result, even though Zera Yaekonb and Kant were taken as pioneers of enlightenment; Zera Yaekob takes a lion share of it. Not only this, but also we have to give recognition as a father of modern philosophy and the originator of enlightenment. Since enlightenment is a logic of thinking rationally up on the most important questions. Therefore Zera Yaekob was an initiator of enlightenment [19].

He introduced the following enlightenment insights, For instance: Public argument and criticism of the three religions have occurred in Aksum. Later a German giant philosopher of enlightenment conferred for a reading public: there must be an expansion of reasoning in religion, politics, and the like, not controlled by the monarchy, aristocracy. Kant said that we allow such freedom and this freedom is okay because there is a special kind of people who have been participating 
scholars, writing for an educated public. Because controversial, precarious utterances could be philosophized by philosophers, so we a need reason as a tool if we want to escape from self-slave and irrationality approaching for daily circumstances. Accordingly, confidentially be obliged to obey even if occupied in communal condemnation of the very things being minded as solid as Zera Yaekob.

As Tatenda Gwaambuka noticed in his article entitled This Forgotten Father of European Enlightenment Ideas Lived in an Ethiopian Cave.

Many of the highest ideals of the later European Enlightenment had been conceived and summarized by one man, working in an Ethiopian cave from 1630 to 1632. In other words, Yacob was the true pioneer of modern philosophy. Yacob advocated for a philosophy based on rationality rather than blind acceptance of claims. He recommended an independent search for truth and illustrated the same by considering various imperatives inherent in the Abrahamic faiths and testing their divinity using the benchmark of human reason [20].

Newly all philosophers of the enlightenment era want to see a strict separation of church and state as well. For they realize that mixing government and religion was all most always leads to disaster. The enlightenment philosopher themselves uses usually Deists, think without traditional religion who believed called natures of God. That is in allpowerful spiritual force that I had created the universe and everything in it and left alone. The ideas of the enlightenment philosophers we deeply admired by the leaders of American Thomas Jefferson and French revolutions. In fact, Thomas Jefferson failback on them time and time again when he composes the declaration of independence.

The last but not the least, as Kant denoted above enlightenment is like omniscient because it considered as a foundation for democracy, equality, a belief in reason, science, religion, etc. as several scholars witnessed the period of enlightenment can't be compared with others period, since no other era of reasoning existed before it. Besides, the principal philosophy for all is how to construct a logical argument, how to make use of reason, and put into practice critical thinking in human's day-to-day activities. In this context, Kant himself noticed that:

The public should enlighten itself is more possible, yes, it is; if one is only allowed freedom, enlightenment is almost sure. For there will always be some independent thinkers, found even among the established guardians of the great masses who, after throwing off the yoke of immaturity themselves to think the spirit of a reasonable estimate of their own worth and every man's vocation, will spread even to themselves [21].

\section{Euro-Philosophers and Their Renunciation Approach: Ignoring Zera Yaekob's Philoosphy}

Chronologically, the age of reason (sometimes so-called enlightenment) started by a French philosopher Descartes and he reflected in his book Discourse on the Method (1637). Thinking using reason has not been stopped with him, but it's continuous until a German philosopher Kant and he reflected in his book Answer the Question: What is Enlightenment? (1784).

However, Aeon Media argued in his article "but what if this story is wrong? What if the enlightenment can be found in places and thinkers that we often overlook? Such questions have haunted me since I stumbled upon the work of the $16^{\text {th }}$ century Ethiopian Zera Yaekob". Furthermore, as Ntep argued:

"Hatataism" is universal because the issues Yacob addressed, then are still relevant today. The man of East Africa ranks among the few thinkers world-wide who have already seriously philosophized on business and labor; thus he stated: "Do not exhaust yourself as animals with no power of thinking, but lay out your work wisely so that you will increase usefulness and profit, and lessen fatigue." In another place, he declares, "Acquire as much as you can without dishonesty." Elsewhere he says, "He who lives on the work of another man while he has himself the ability to work is a chief and a plunderer." Eventually, Claude Sumner wrote: Modern Philosophy, in the sense of a personal rationalistic critical investigation, began in Ethiopia with Zera Yaekob at the same time as in England and in France. We'll just add, Modern Philosophy and the Enlightenment reached their peak with Zera Yacob, of Ethiopia in Africa [22].

I am saying this, preliminary; let's introduce the wellknown French philosopher René Descartes because his philosophical work has tremendous relevance with the Ethiopian scholar. Descartes was born on 31 March 1596 in the small town of La Haye-France. The method Descartes employs in the 'Meditations' to achieve this has become known as his 'method of doubt'. Thus he begins not by stating things which he thinks are true and building upon them, but by asking the simple question as solid as Zera Yaekob, 'Is there any one thing of which we can be utterly certain?' In gearing the predicament in this way, Descartes attempts to find the one thing beyond all doubt upon which we can build our knowledge the very first principle, so to speak. Accordingly, the paper is intended to provide a clear and simple to grip the overview of the Zera Yaekob with both euro-philosophers particularly Descartes and Kant's argument on enlightenment. As Ntep reflected in his article:

If the French René Descartes is regarded as the pioneer of "Modern Philosophy", if many believe that Kant - the philosopher who borrowed the concept of the "Thing in itself" or "Noumenon" from the Amo, the philosopher of Guinea in Africa - is the "greatest philosopher" of the "European Enlightenment", then all those who're hip to and familiar with the treatises of Zera Yacob or Zar'a Ja'aqob would argue with me that the works of this East African philosopher represent the climax of both "Modern Philosophy" and the "Age of Enlightenment" [22].

During the enlightenment period in the human ability to reason was glorified. Accordingly, Descartes argues that the 
corridor to attain truth is with human reason alone. This corridor is known as "rationalism". At the beginning of the enlightenment period or during the first half of the 700 century a man his name Rene Descartes published an important book that came to inspire generations of enlightenment scientists, philosophers, and scholars. In fact, many historians considered this French man to be the father of the enlightenment.

Simultaneously, Zera Yaekob argued that everything had been designed by all-powerful God. He was highly engrossed on God's metaphysical formulating of the universe. In this connection, the existence of God was proved by Zera Yaekob through his own methodology. Besides, his new methodology of discovering God is so-called "rationalistic God". The ideas promoted by a native Ethiopian philosopher and his spokesperson Welde Hewet verified to be extremely imperative because they lead to development.

Therefore, as the use of the rationalistic method developed by Zera Yaekob had a great role in the existence and emergence of European enlightenment/utilizes reason and incredible brought the understanding of European enlightenment thinkers, especially for Kant's enlightenment and Europeans as a whole, occurred. Thanks to Zera Yaekob or he is considered as a stepping stone for the opening of European enlightenment. As a result, it was greatly accelerated the enlightenment revolution in Europe and it follows Renaissance.

Therefore, Ethiopian philosopher Zera Yaekob's thinking was a bell for euro- philosophers and they hold-sustain at alarming rates. In this line, let me borrow a word from the Greek philosopher Socrates "gadfly", of course, he had seen for himself as a gadfly/midwifery but numerous reasons can tell to Zera Yaekob as a gadfly for those who have a habit to interpret holly books figuratively and allegorically. What a sad here is that the world has very little information about the architect of enlightenment, Zera Yaekob. So, modern intellectuals and societies have forgotten the role of Zera Yaekob and they have thrown his enlightened mind to the hall. As a Canadian philosopher noted, in the modern period before Descartes, an Ethiopian philosopher Zera Yaekob was the first philosopher who used reason for social, gender, religion, epistemology affairs. His idea was as follows:

One day I said to myself in my own thought 'whom am I praying to or is there a God who listens to me?' At this thought I was invaded by dead full sadness and I said: 'In vain have I kept my own heart pure (as David says). Later on I thought of the words of the same David, 'Is the inventor of the ear unable to hear?' and I said: 'who is it that provided me with an ear to hear, who created me as a rational [being] and how have I come into this world? Where do I come from? Had I lived before the creator of the world, I would have known the beginning of my life and of the consciousness [of myself] that created me [23]?

This paragraph surly deduces that he was able to understand a rational formulating the commandments of the Bible and Quran. As a result, Zera Yaekob was quarreling with those who have the ambition to be a dogmatic priest and with lovers of traditional worshiping of God. All this has been reflected in his book. Additionally, his book radically changed the understanding of European enlightenment thinkers. So, he has played an immense role in creating a rational modern society, politics, science, religion, and technology.

Philosophers denoted the philosophical word metaphysics, which can be defined as the study of reality in a broad sense. It can be also defined as the study of transcendental reality, which lies beyond the physical world and cannot be grasped by means of empirical observations. Super naturalists understand Metaphysics in its broader sense because they raise questions of reality like 'what is a reality?' What is real/, is it one or many? And so on. They also understand metaphysics in its narrower sense because they believe in supernatural or transcendent reality, say God. Accordingly, Zera Yaecob and Welde Hiwot raised those and similar questions because of this they can be categorized as a super naturalist philosopher. Let us first look at the method of Zera Yaecob, which was used to prove the existence of God.

He raised metaphysical questions like, "How does God know; or is there anyone in heaven who knows? Or if there is one who knows, why does He remain silent on man's depravity while their corrupt His name acts with iniquity in His holy name" [24]?. ZeraYaecob raised these questions because he observed that the followers of every religion argued as if their faith was true and the other's faith was false. They were defending their own faith while rejecting other faiths. Moreover, he was praying that his God would make him intelligent and reasonable in order to be able to know the hidden wisdom of God. He tried to prove whether there is a God or not using his own metaphysical theory.

As I have endeavored to point out on the above paragraph, the method of doubting used by Zera Yaecob to prove the existence of God like the French philosopher and father of modern philosophy did. And it also shows that Zera Yaecob didn't accept God as an unquestionable entity because of this it may be possible to say that Zera Yaecob's God wasn't the same as that of the Christian's God, which is unquestionable and blindly accepted through faith.

After proving the existence of God, Zera Yaecob questioned whether everything that is written in the Holy Scripture is true or not. He wanted to consult scholars and thinkers, but he realized that these individuals would tell him only what they were supposed as true or they would tell him only the rightness of their own faith. Because of this they can't be taken as neutral judges. He also examined the written documents of other religions and concluded that there are true as well as false concepts so that we have to distinguish false from the truth through rationalization of these concepts. This shows that Zera Yaecob didn't accept Christianity and the Holy scripture as they are. He rejected some of the points, which don't have any rational basis. Because of this, Zera Yaecob's religious ideology, as well as his God, was to some extent different from Christians, and other religious ideologies. Therefore, he has his own Meta physical foundation for the existence of God. 
Welde Hewet also raised Metaphysical questions about the existence of God. He used empirical methods to prove the existence of God. According to him, all the things we see in this world, including ourselves, are transitory and created. But how can they be created without a creator? Because each creature is finite and weak; it has no power to be created from nothing. Therefore, there needs to be one essence, that existed before all creatures, without beginning or end, that created from nothing all that is dense and thin, visible and invisible- i.e. God. For him, the perfection of God can also be understood from his creatures [25].

All that has created is very good in the way he created it. Some people may classify things as useful and useless because they are unable to understand in the way God created them. Hence, some things, which were considered as useless in the past, become useful in the present. This shows that the human mind is less perfect than God. Because of this, people can't understand everything in the way they are created. Therefore, for Welde Hewet, God is created out of nothing and every creature of his has purposed. But since the human mind unable to understand the whole works of God, people may consider some of the creatures useless.

The main concern is not to show his philosophy of metaphysics rather show his contribution to European enlightenment, but the above description is only so know how he utilized reason in metaphysical issues. Analogously, European Enlightenment is really with the time when people talk to the ideas and use their own minds based on reason. Human societies asking the question of why things would through tried to find the solution to a lot of man's problems. If this is the nature of Enlightenment, then Zera Yaekob has finished even before Descartes and Kant and all enlightenment thinkers the questions of how we use reason and how we think rationally plus he has discovered a rationalistic approach to solve any human's challenges [26].

His objective was ultimately to rely on human reason, rationalism, and the build of mind to build problems in order to try getting a better society for everybody to try to minimize humans suffering as much as possible, including religious puzzling.

Analogously, European applies reason to escape from religious-based life to reason-based life. And Europe in that period there was an enormous alters world in times of in a way people view governed. For a long history of a Welde Hewet, there were kings (the king had an absolute monarch or power). The divine gives any order of the king and the king also orders for the people what to do. The unique characteristics of the pre-European enlightenment period were based on religion. The existence of the state is related to the idea of God - the source of power is God. Due to reasoning that emerged during enlightenment there were a number of philosophers who started the question the concept of kings has an absolute power or king's responsibility to God.

The least but not the last, during Zera Yaekob's lifetime the following affairs have been successfully activated.

1 Religion granted control over human life to powerful priests.

2 The rise of a monotheistic religion with the theme of submission before God, God's role in human affairs, obedience and duty in earthly life to receive the rewards of the afterlife. Therefore, the keynote theme of the Orthodox Church was to balance earthly power and the power of God, dogmatically.

3 The problem of evil and holiness of goodness.

But how it could be a rational religion in the absence of rationalistic God/religion? However, the question has been overthrown by the Ethiopian man /philosopher. Zera Yaekob has applied logic as a tool and discovered rational religion in general and God in particular plus God will be provided only and only through human intellect, conscience [27].

Therefore, after overthrowing faith-based religion/thinking reason-based God/religion begins ironically around the $16^{\text {th }}$ century by the untold philosopher but to be tolled Zera Yaekob. Accordingly, his philosophical legacy or the following are the impacts of the philosopher to modernity:

i. New found space for human agency-a reawakening.

ii. More concerned about rational implications of ethics, religion, metaphysics, epistemology and the like.

iii. Reason, logic, perception, observation, human experience acquires new found value rather than divine guidance. In accordance with this, Zera Yaekob is a key figure in this paradigm shift.

However, If this is a man his name Zera Yaekob why he has been ignoring by euro-philosophers, yet? And why Descartes and Kant didn't acknowledge his spectacular philosophy? The answer is well known because of their philosophizing and systematically renunciation approach towards Ethnocentric or Afro-centric philosophy of enlightenment since Africa in general and Ethiopia, in particular, is the authorship and spring of enlightenment.

Surprisingly but terribly also, finally, they are there with the light of enlightenment because we are here with the twilight of counter-enlightenment.

\section{Conclusion and Recommendation}

Enlightenment (sometimes so-called the age of reason) is also pictured as a fall of dogmatism. The great Ethiopian philosopher Zera Yaekob interpretation of, so use an element in his designation of the Orthodox Church, Catholic and Islamic thought, though neglected by the priests and the king of Axum, but thanks to the power of reason his writings have made we awaken from our daydreaming because of Zera Yaekob.

He was the only person who has enlightened himself and us too from men's dogmatism. According Zera Yaekob to be human if and only if his/her life in compasses with the respect of the "the power of reason" to know the truths of nature and the capacity of the human spirit to determine, express, and achieve what is good for human beings.

Loads of scholars like Lavine argued that "Renaissance art reaffirmed the dignity and capacity for the goodness of man 
as a rational and sentient being”. From a philosophic arena, an extraordinary development was emerged due to applying reason to our day-to-day activities and several achievements were realized, for instance, in searching metaphysics, epistemology and the way to interpret the Bible and who is the going to interpret the Bible.

Paradoxically, Ethiopian Orthodox Church was taken a lion share of interpreting the Bible and any affairs, divinely. Finally, they certainly believed the metaphysical utterances are grasped merely by praying, but it is not cacheable to the power of reason. However, Zera Yaekob has escaped from the cave of thinking and has shown to them the necessity of reason even to know metaphysics.

Later, the spirit of using in constructing any human arguments moved on and still alive with some amendments. The Zera Yaekob spirit of reasoning was migrated to Europe and numerous philosophers of enlightenment were influenced by him, for instance from René Descartes till Immanuel Kant These two euro-philosophers, though have seen based on their own context and form. As a result, new science, the methodology was flourishing. As Lavine suggested the new "scientific method" are (I) the empirical element, the use of sensory observation and experimentation (II) the rational element, deduction reasoning [28].

This deduces that year after year, month after month, day after day, hour after hour Zera Yaekob philosophy continued even though those who influenced euro-philosophers have neglected/denied his reasoning. If so euro-philosophers should send a request of forgiveness. Despite, the researcher doesn't think they will do because the whites will never see themselves as subordinates of the black. And now is a time to appreciate and acknowledge Zera Yaekob's comprehensive knowledge/philosophies.

To conclude, there was a philosopher who lived four hundred years ago in Axum-Abyssinia (today Ethiopia), whose name Workye, later Zera Yaekob. He was a killer of irrationality investigation/inquiry of metaphysics/reality, epistemology/knowledge, religion, and gender. However, at the same time he was ignored by the so called europhilosophers by saying that irrationality was killed by Europeans, but not by Africans in general and Ethiopian in particular because they believed Africans have not a reason and enlightened mind to do that.

Finally, they simply restated and re philosophized of Zera Yaekob's philosophy of enlightenment through developing a renunciation approach/method; it is a method of throwing to the cliff and alienating African's philosophy, science, and religion. Among the many Ethiopian philosophers Zera Yaekob was a number one of those who infected by their method. When irrationality dies rationality began and it was killed by Zera Yaekob though Europeans systematically and philosophically ignored the enlightenment that was never seen before them. Accordingly, he can be considered as a pioneer and architect of the European enlightenment project and it has a tremendous role in the existence of African philosophy.

\section{References}

[1] Claude. Sumner. (1976). Ethiopian Philosophy: The treatise of Zär'a Ya'aqob and of Wäldäqaywdt Text and Authorship, Vol. II, Addis Ababa University Printing Press.

[2] Deligiorgi, Katerina. (2005). Kant and the Culture of Enlightenment: State University of New York Press.

[3] Sumner. Claude. (2004). The Light and the Shadow: Zera Yacob and Walda Heywat: Two Ethiopian Philosophers of the Seventeenth Century. Blackwell Publishing Ltd.

[4] https://aeon.co/essays/yacob-and-amo-africas-precursors-tolocke-hume-and-kant.

[5] Miller, L. ED. (1984). Questions That Matter: An Invitation to Philosophy. McGraw-HILL Book Company.

[6] K. J. Marx. (2009). The Usefulness of The Kantian Philosophy. Ridderprint Offsetdrukkerij.

[7] Teodros. Kiros. (2004). Zera Yacob and Traditional Ethiopian Philosophy. A Companion to African Philosophy. Blackwell Publishing Ltd.

[8] Berlin. Isaiah. (1956). The Age of Enlightenment: The Eighteenth-Century Philosophers. Oxford the Isaiah Berlin Literary Trust.

[9] S. J. Barnett. (2000). The Enlightenment And Religion: The Myth Of Modernity. Manchester University Press.

[10] Kant, Immanuel. (1784). Answer the Question: What is Enlightenment? Konigsberg in Prussia.

[11] Lavine, T. Z, (1984). From Socrates To Sartre: The Philosophic Quest. New York.

[12] Kiros. Teodros.(2004). Zera Yacob And Traditional Ethiopian Philosophy. A Companion To African Philosophy. Blackwell Publishing Ltd.

[13] Goldmann. Lucien.(1973). The Philosophy of the Enlightenment The Christian Burgess.

[14] Nuovo. Victor. (2011). Christianity, Antiquity, and Enlightenment: Interpretations of Locke. Springer.

[15] Kelley. R. Donald. (1991). Versions of History from Antiquity to the Enlightenment. Yale University Press, New Haven \& London.

[16] Teodros. Kiros. (1996). Claude Sumner's Classical Ethiopian Philosophy. Northeast African Studies, New Series, Vol. 3, No. 2 (1996), pp. 39-52.

[17] Marx. J. K. (2009). The Usefulness of The Kantian Philosophy. Ridderprint Offsetdrukkerij Bv, Ridderkerk.

[18] https://www.africanexponent.com/post/9551-african-thoughtleaders-embraced-enlightenment-before-europ).

[19] https://zelalemkibret.files.wordpress.com/2013/10/zarayaaqob-the-ethiopian-philosopher-founder-of-hatata

[20] Paine, Thomas. (1796). The Age Of Reason: The Writings Of Thomas Paine. Vol. IV. The Project of Gutenberg.

[21] Rober, B. Louden. (2007). The World We Want. Oxford University Press. And the Enlightenment. Routledge \& Kegan Paul London. 